\title{
Integration of Environmental Education at the Adiwiyata Program Recipient School in Growing Ecoliteracy of Students
}

\author{
Dhea Adela \\ Sebelas Maret University \\ Surakarta, Indonesia \\ dheaadela@student.uns.ac.id
}

\author{
Sukarno \\ Sebelas Maret University \\ Surakarta, Indonesia \\ sukarno57@gmail.com
}

\author{
Mintasih Indriayu \\ Sebelas Maret University \\ Surakarta, Indonesia \\ mientasihindriayu@yahoo.com
}

\begin{abstract}
This research is a descriptive and explorative research that aims to find out how the integration of environmental education in Adiwiyata recipient schools in growing the students' ecoliteracy through intracurricular and extracurricular program. This research uses qualitative approach with case study method conducted in one of public elementary school which has received Adiwiyata award 2018. Technique of collecting data using interview, observation, and curriculum document study. The data has been collected and then reduced, analyzed, and trianggulation so that the description of research results. The subjects were six teachers including principals and ten students from different classes who were elected and considered to represent various views on environmental education at the school. From the results of research indicates that environmental education has been implemented through intracurricular program integrated in learning activities and also through extracurricular program. Teachers and students have implemented environmental care attitudes in a proactive manner based on the Adiwiyata-based curriculum and in the effort to foster student ecoliteracy. However, the Adiwiyata award is more prominent artificially in ecofriendly physical symbols when compared to the consistent establishment of eco-friendly culture throughout the school community. There is still a need for continuous support and effort from all school residents to shape the ecoliteracy culture and create an environmentally sound school.
\end{abstract}

Keywords- Environmental Education, Ecoliteracy, Adiwiyata Programme, Elementary School

\section{INTRODUCTION}

Humans and the environment is a unity in shaping the ecosystem and depend on the surrounding environment, be it the natural environment (physical) and social environment. Urgency of efforts to preserve the natural environment is the responsibility of the world community as the earth's inhabitants and users of natural resources. Eryaman (1) argues that the ecological crisis is a vital issue facing all humans. Therefore, education is essential for the development of environmental awareness and to strengthen the ability of individuals and communities to resist actions that can lead to environmental crises.

Environmental analysis is always concerned with human impacts through the fulfillment of life needs of all elements in the environment. This perspective can be seen from several aspects of the environment including biological, physiological, economic, and cultural aspects that are interconnected with one another. As a global ecosystem, the earth is shaped and influenced by smaller systems including the individual's perspective of understanding where he lives. In the self, the perception of place and space is processed through the skill of thinking and manifested in the behavior of the surrounding environment which is a unity can not be separated, as Tsegay (2) argues that one of the development of citizenship is to treat the earth as part of their life together in harmony.

Education has a fundamental role in shaping the character of learners to always have sensitivity and awareness of the surrounding natural environment. This is relevant to Sapriya's (3) opinion that learners need to be prepared to respond to ecological crises by establishing attitudes and care as a form of human responsibility for a common future and sustainable living. The ongoing environmental issues remind us of the importance of environmental awareness. This awareness is called ecological consciousness or Ecoliteracy.

Factually, growing an environmentally conscious attitude that is part of ecological intelligence (ecoliteracy) has not been fully realized. Students do not yet have an environmental concern as expected. Muhaimin (4) indications in some cases is still a lot of dirty school environment, students' participation in environmental activities are still low, the lack of awareness of students in shaping environmental behavior, wasteful behavior in the use of natural resources, apathy towards environmental preservation around students, and etc. Accordingly, Okur (5) argued that environmental attitudes include the goals of one's behavior, impact, and beliefs derived from the subject or activity of the environment and 
mentioned that environmental attitudes can be used to predict behavior on the environment.

Ecoliteracy is a new paradigm popularized by Fritjof Capra, aimed at increasing the ecological awareness of society. Capra in McBride (7) reveals coined the term ecoliteracy, defined as an understanding of the principles of the organization of ecosystems and the application of those principles for creating sustainable human communities and societie. Ecoliteracy seeks to introduce and renew people's understanding of the importance of global ecological awareness, to create a balance between the needs of society and the ability of the earth to sustain it. Goleman (7) ecological intelligence is our ability to adapt to the ecological niche we are in. Ecological intelligence is based on three domains of knowledge, attitudes, and behavior of living in harmony with the natural environment.

Orr (20) an ecologically literate person has a basic comprehension of ecology, human ecology and the concepts of sustainability. Ecological intelligence is important as the UN sustainability development paradigm is enhanced through Earth Charter generated at the Earth Summit in Rio de Janeiro in 1992. The conference recommended activities to support sustainable development through education that is integrated into interdisciplinary at all school level. Education is needed to boost the community's ability to cope with various development issues related to the environment.

Environmental education is an important component in environmental protection and management, especially in instilling community behavior in order to integrate the environment in every decision making. In 2006 the Ministry of Environment launched the Adiwiyata Program as a follow-up to the MoU between the State Minister for the Environment and the Minister of National Education which aims to realize a caring and cultured school environment through the training of Adiwiyata to the school. The meaning of the word Adiwiyata is a good and ideal place where can be obtained all the science and various norms and ethics that can be the basis of humankind towards the creation of the welfare of our lives and toward the ideals of sustainable development.

Elementary school recipient of Adiwiyata 2018 award has potential physical environment facility to be managed and utilized as environmental learning media in school. This research focuses on the integration of environmental education in Elementary School recipients of Adiwiyata Award in fostering the ecoliteracy of students as well as efforts made by the school community to improve students' knowledge, skills and awareness about environmental values.

\section{RESEARCH METHODS}

This research is a descriptive and explorative research that aims to find out how the integration of environmental education in Adiwiyata recipient schools in cultivating the ekoliterasi students through intrakurikuler and extracurricular program. This study used a qualitative approach with case study methods conducted in one of the public elementary schools that have received the Adiwiyata 2018 award. Data collection techniques used interviews and observations to obtain a description of the implementation of learning activities in the context of integration of environmental education in schools and curriculum document studies namely syllabus and learning implementation plan (RPP). The data were collected and then reduced, analyzed, and triangulated to get the description of the research results. The subjects of the study were six teachers including principals and ten students from selected classes and considered to represent the various views on environmental education in schools.

\section{RESULT AND DISCUSSION}

\section{Theoretical Aspects}

Environmental ethics suggests a new perspective on human positions in the order of the universe and a new perspective on the importance of bringing students closer to the environment in which they live. Building ecological intelligence (ecoliteracy) is one of them. Kim (18) revealed thatcomprehensive definition of ecoliteracy as the ability of individuals to identify names, uses, and related stories of living organisms and natural phenomena in their local ecosystems. Goleman (8) suggests that humans are part of nature can be manifested through five actions, such as: a) developing empathy for all from of life; b) embracing sustainability as a community practice; c) making the invisible visible; d) anticipating unintended consequences; e) understanding how nature sustains life. Tursi (21) below is a graph showing the relationship between ecoliteracy, environmental education (EE), and education for sustainability (EfS).

DIAGRAM I. ECOLITERACY, ENVIRONMENTAL EDUCATION, AND EDUCATION FOR SUSTANABILITY RELATION

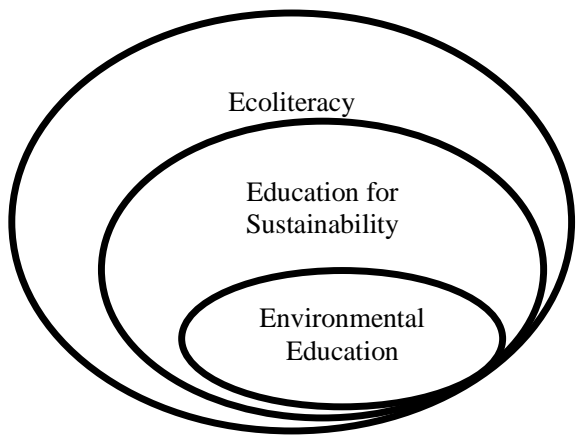


Graphic showing how EE, EfS and Ecoliteracy fit within one another. As you can see from the graphic, $\mathrm{EE}$ is only a part of EfS, and that EfS is a means to an end, and in this case, the end is ecoliteracy. This example is taking the notion that although EE and EfS are two different pedagogies, EE can still fit into EfS. Capra (19) schools are not separate from the communities in which they operate, and to recognize this fact is the beginning of ecoliteracy and sustainability.

Supriatna (9) argues that the Adiwiyata recipient school is one of the most conducive places for the development of empathy for fellow human beings, other living beings and the environment. Empathy towards all life forms can be developed by integrating environmental material in learning. Integrated classroom learning provides knowledge of all lifeforms created to be related to their existence in the environment in which they live.

The Adiwiyata Program is a program of the Ministry of Environment No. 02 of 2009. This program is a form of appreciation given by the government to the formal education institutions that are considered meritorious in developing environmental education (10). The objective of the Adiwiyata program is to realize responsible schoolchildren in the effort to protect and manage the environment through good school governance. There are four components of the program that are integrated into the Adiwiyata school, ie a) development of environmentally sound school policy, b) implementation of environment-based curriculum, c) participatory and participatory environmental activities, and d) management of environmentally friendly means of support (10).

Adiwiyata award is given as a form of appreciation to schools that are able to carry out efforts to improve environmental education properly, in accordance with predetermined criteria. Learning experience expected from students as implication of Adiwiyata based instructional device which developed by teacher is student doing activity of learning both intrakurikuler and ekstrakurikuler about environmental protection and management. Schools that have committed to become Adiwiyata schools must have an Adiwiyata-based curriculum that is outlined in the form of learning tools syllabus, lesson plan (RPP), book, and Adiwiyata based learning test. Supriatna (9) in the curriculum has integrated at least two major issues of education today that is education of nation character and environmental education.

\section{Field Studies}

From document analysis, it was found that schools have developed and integrated efforts to develop environmental education into extracurricular programs such as environmental ambassadors and scouts. In learning are integrated activities such as waste management, medicinal plants, biopori seedling, recycling, energy saving, personal hygiene and environment. Through this activity can be seen that the school community is able to develop environmental education through intrakurikuler and extracurricular activities. Deborah (11) one of the goals of environmental education is the development of environmental literacy.

Environmental awareness values in Adiwiyata recipient schools are integrated into subjects contextually based on the 2013 curriculum and included in the syllabus and lesson plan (RPP). From document analysis, researchers found that integrating environmental education values in the school into learning through multiple subject indicators was supported by developing lesson plans, method selection, learning material development, and assessment instruments both inside and outside the classroom. However, not all standards of competence (SK) and basic competence (KD) can be integrated environmental education materials administratively.

\section{Interview}

Based on interview results, teachers are committed to developing competency standards and basic competencies (KD) at the beginning of the school year to determine aspects to be integrated into learning and facilities in school environments that can be used such as school yards that can be used for land greening.The results of interviews with the principal explained that initially received less support from some teachers in integrating environmental education to all school residents, especially students. Then coaching is done by holding workshops on integrated learning environment towards sustainable development education as stated by Kopnina (13) implications of environmental education towards education for sustainable development in the context of environmental ethics. Below is a learning activity developed by teachers with the integration of environmental education as well as expected student activity indicators.

\section{TABLE I. LEARNING ACTIVITIES DEVELOPED BY TEACHERS WITH ENVIRONMENT EDUCATION} INTEGRATION

\begin{tabular}{|c|c|}
\hline Developed Learning & Student Activity Applied \\
\hline $\begin{array}{l}\text { 1. Learning resources } \\
\text { other than books in the } \\
\text { form of movie } \\
\text { impressions in } \\
\text { accordance with the } \\
\text { expected compotence }\end{array}$ & $\begin{array}{l}\text { 1. Take out the garbage } \\
\text { in its place } \\
\text { 2. Bring your own } \\
\text { bottle of drink from } \\
\text { home } \\
\text { 3. Get used to using a } \\
\text { handkerchief }\end{array}$ \\
\hline $\begin{array}{l}\text { 2. Concrete, in the form of } \\
\text { examples of events }\end{array}$ & $\begin{array}{l}\text { 4. Reduce the use of } \\
\text { tissues }\end{array}$ \\
\hline
\end{tabular}




\begin{tabular}{|l|l|}
\hline $\begin{array}{c}\text { that occur students } \\
\text { environment }\end{array}$ & $\begin{array}{l}\text { 5. Maintain the existing } \\
\text { plants in the school } \\
\text { environment }\end{array}$ \\
\hline $\begin{array}{l}\text { 3. Student center, students } \\
\text { can choose behavior } \\
\text { that can support } \\
\text { environmental } \\
\text { preservation }\end{array}$ & $\begin{array}{l}\text { 6. Familiarize a clean } \\
\text { minute before going } \\
\text { home from school }\end{array}$ \\
\hline $\begin{array}{l}\text { 4. Applied with practice } \\
\text { and habituation }\end{array}$ & recyclable items \\
\hline
\end{tabular}

\section{Observation}

Observations were made related to the integration of environmental education in Adiwiyata recipient schools, this can be observed from the application aspect of action applied to the students as a habituation called the Green House program. The instruments used are the observation sheet and the questionnaire. There are two aspects observed, namely aspects of knowledge and aspects of the application. Aspects of knowledge referred to in this study that students are able to understand the concept of green environment and understand how to maintain the environment and have an understanding how to use organic and inorganic waste. Aspects of application in this study is an action that reflects ecoliteracy. Inna (17) argues that future leaders as ecoliterate will have developed an enhanced perception, a sense of value-judgment in experience and sustainable self and other relations. Student behavioral indicators that show ecoliteracy include not littering, able to take advantage of organic and inorganic waste, and participate in maintaining the existing plants in the school environment as Green House program. Involving students interacting directly with environmental conservation activities has implicitly established a responsibility attitude as Lauren (14) argues that providing opportunities for children to be close to nature and spending time outside the home may indicate a predictor of responsible environmental behavior.

\section{PICTURE 1. ACTIVITY TO RESERVE THE USED GOODS}

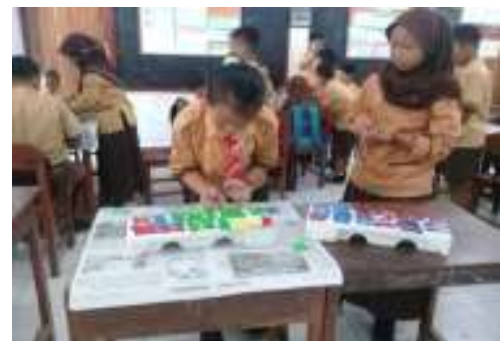

Adiwiyata recipient school there is an integration of environmental education by applying the habit of environmental care in fostering the ecoliteracy of students through Green House activities that involve students to contribute to care for plants in the school environment. This is one of the efforts to build a sustainable society through environmental education as stated by Joanne (12).

\section{PICTURE 2. STUDENT CONTRIBUTION THROUGH GREEN HOUSE ACTIVITIES}
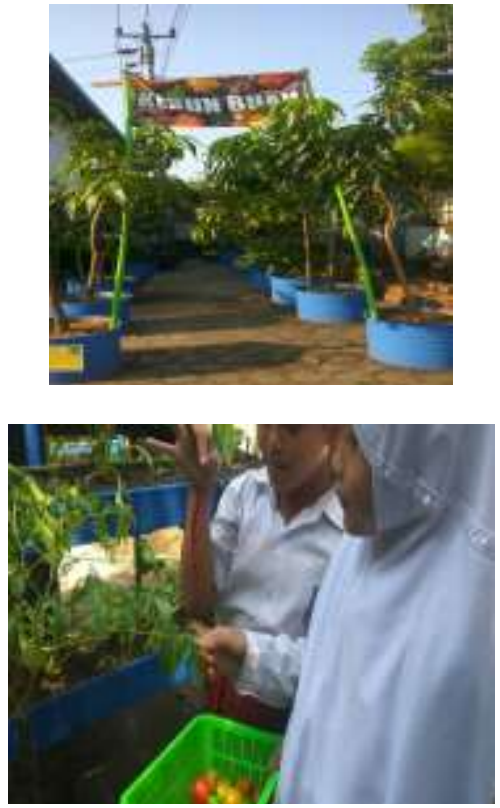

As the Adiwiyata recipient school helps students tend to adhere to various initiatives around environmental concerns as students view as examples rather than rules. Environmental education is not only carried out as a theory but also a practice as revealed by Locke (15) that redesigning education for the purpose of creating ecological sustainable communities is one of the most critical needs of today's society at both global and local levels. Students have group learning experiences in and out of the classroom. Students also become more easily exposed to topics around environmental awareness such as saving energy, recycling waste, and disposing of waste according to their kind.

There are some difficulties at the start of school attendance for the various environmental awareness 
programs that this school is holding. But then they become accustomed and they are happy to contribute and show their commitment to the school program in the integration of environmental education. The students' environmental awareness behavior is the result of their creativity that begins with the cultivation of environmentally conscious habits in schools as stated by Spinola (16) that the main goal of environmental education is to improve the environmental literacy, environment and a higher prevalence of pro-environmental behaviors.

\section{CONCLUSION}

Based on the result of the research, it can be concluded that Adiwiyata Mandiri recipient elementary school has integrated environmental education with the aim of establishing clean, comfortable and cool school for the students through environmental programs and activities referring to stakeholder decisions through proactive and coordinated action of the citizens of the school to create a clean, healthy and cultured school environment. Implementation of learning activities in the context of the integration of environmental education in schools is done by involving students to utilize used packaging into useful items and to do the habit of caring for the environment in growing the students' ecoliteracy through Green House activities which involve students to contribute to care for the plants in the school environment. The integration of environmental education has succeeded in growing the students' ecoliteracy. This is evident from the increased ecoliteracy obtained by students, both from aspects of knowledge, conscience, and also the application.

\section{ACKNOWLEDGEMENT (Heading 5)}

Thank to our lecturers and our colleagues from Sebelas Maret University who provided insight and expertise that greatly assisted the research.

\section{REFERENCES}

[1] Eryaman, M. Y., Yalçı̈Özdilek, "A Participatory Action Research Study of Nature Education in Nature: Towards Community-based Eco-pedagogy", International Journal of Progressive Education, vol. 6(3), pp. 26-37, 2010.

[2] Tsegay, S.M, "Analysis of Globalization, the Planet and Education", International Journal of Environmental \& Science Education, vol. 11(18), pp. 11979-11991, 2016.

[3] Sapriya, "Pendidikan IPS", Bandung: Remaja Rosdakarya, p.135, 2011.

[4] Muhaimin, "Membangun Kecerdasan Ekologis", Bandung: Alfabeta, p.13, 2015.

[5] Okur, E, \& Berberoglu, "The Effect of Ecopodagogy-Based Environmental Education on Environmental Attitude of Inservice Teachers", International Electronic Journal of Environmental Education, vol. 5(2), pp.86-110, 2015.
[6] McBride, B. B., C. A. Brewer, A. R. Berkowitz, and W. T. Borrie, "Environmental literacy, Ecological Literacy, Ecoliteracy: What do we mean and how did we get here?"

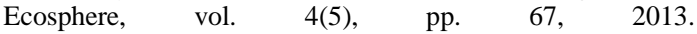
http://dx.doi.org/10.1890/ES13-00075.1

[7] Goleman, D, "Ecological Intelligence: How Knowing The Hidden Impacts Of What We Buy CCn Change Everything" (Edisi Bahasa Indonesia). Jakarta: Gramedia Pustaka Utama. p. 37,2010

[8] Goleman D, Bennet L, Barlow Z, "Eco Literate, How Educators are Cultivating Emotional, Social, and Ecological Intelligence", San Francisco: Jossey-Bass. p. 10, 2012.

[9] Supriatna, N, "Ecopedagogy Membangun Kecerdasan Ekologis dalam Pembelajaran IPS”, Bandung: Rosdakarya, p. 340-341, 2016.

[10] KLH, "Kementerian Lingkungan Hidup Dewan Adiwiyata", Jakarta, Indonesia, 2012.

[11] Deborah, D., Eames, C., \& Calder, N, "Impact of Environmental Education on Beginning Preservice Teachers' Environmental Literacy". Australian Journal of Environmental Education, vol. 33(3), pp. 201-222, 2017.

[12] Joanne, O'Flaherty \& M. Liddy, “The Impact of development Education and Education for Sustainable Development Interventions: a Synthesis of the Research", Environmental Education Research, 2017, doi: 10.1080/13504622.2017.1392484

[13] Kopnina, Helen, "Education for Sustainable Development (ESD): the Turn Away from 'Environment' in Environmental Education?", Environmental Education Research, vol. 18(5), pp. 699-717, 2012.

[14] Lauren, E., Andrejewski\& Andrew, J, "Connecting Children to Nature through Residential Outdoor Environmental Education". Environmental Education Research, 2018, doi: 10.1080/13504622.2018.1458215.

[15] Locke, S., Russo, R.O, \& Montoya, C, "Environmental Education And Eco-Literacy As Tools Of Education For Sustainable Development", Journal of Sustainability Education, vol. 4, January 2013.

[16] Spinola, H, "Environmental Literacy Comparison Between Students Taught in Eco-Schools and Ordinary Schools in the Madeira Island Region of Portugal", Science Education International, vol. 26(3), pp. 395-416, 2015.

[17] Inna, Semetsky, "Ecoliteracy and Dewey's educational philosophy: implications for future leaders", Foresight, vol. 12(1), pp. 31-44, 2010, https://doi.org/10.1108/14636681011020164.

[18] Kim, G., "Enhancing Ecoliteracy through Traditional Ecological Knowledge in Proverbs", Sustainability, vol. 9(7), pp.1182, 2017, doi:10.3390/su9071182.

[19] Capra, F, Speaking Nature's Language: Principles for Sustainability. In M. K. Stone, \& Z. Barlow, "Ecological Literacy: Educating Our Children for a Sustainable World". p.18-29. San Fransico: Sierra Club Books, 2005.

[20] Orr, David, "Ecological Literacy: Education and the Transition to a Postmodern World", Albany: State University of New York, 1992.

[21] Tursi, Joseph M, "DIPR: Holistic Education Integrating Sustainability and Ecoliteracy into K-12 education in the US”, United State: Philadelphia University, 2015. 